6. Scott Fredrickson, Using Games in Online Education: Is it a Winning Strategy?, University of West Georgia, Distance Education Center, Online Journal of Distance Learning Administration, Volume XVII, Number IV, Winter 2014

7. Susan M. Gass, Larry Selinker SECOND LANGUAGE ACQUISITION An introductory course Third edition Routledge, Madison Ave, New York, 593 p.

8. Teacher Learning in Difficult Times: Examining Foreign Language Teachers' Cognitions About Online Teaching to Tide Over COVID-19, Front. Psychol. [Electronic resource] - Access mode: https://doi.org/10.3389/ fpsyg.2020.549653, 15 September, 2020

9. Thomas S.C. Farrell and George M. Jacobs English Language Teaching, 2010, 141 p. (p 27).

DOI https://doi.org/10.30525/978-9934-26-073-5-2-65

\title{
СТРАТЕГIÏ І ТАКТИКИ НАВЧАННЯ ПОЕТИЧНОГО ПЕРЕКЛАДУ
}

\author{
Ємець Н. О. \\ кандидат філологічних наук, \\ викладач кафедри англійської і німецької філологї та перекладу \\ імені професора I. В. Коруния \\ Київського наџіонального лінгвістичного університету \\ м. Київ, Украӥна
}

Навчання стратегіям i тактикам поетичного перекладу займає важливе місце у структурі навчального процесу підготовки професійних перекладачів. Ця дисципліна орієнтована на вивчення загальної теорії перекладу художнього тексту як особливого типу мислення, світосприйняття, рефлексії та саморефлексії [2]. Щобільше, художні тексти у цілому і поетичні зокрема без перебільшення можна вважати найвищим творчим виявом митця і культурним багатством народу. Невід'ємним компонентом методичної складової дисципліни $є$ іï тісний зв'язок 3 такими курсами, як «Перша мова», «Теорія і практика перекладу», «Основи художнього перекладу» та інші.

Уведення до навчальної програми курсу 3 поетичного перекладу викликано потребою ознайомити майбутніх перекладачів 3 розвитком дисципліни у іiі історичні перспективі. Такий підхід забезпечує 
системність висвітлення проблеми художнього перекладу у їі взаємозв'язку з історією і теорією літератури, культурологією, лінгвопоетикою та іншими дисциплінами, що завдяки міждисциплінарності досліджень сприяють всебічним пошукам і у перекладацькому річищі.

Зазначений курс спрямований на ознайомлення студентів зі специфікою поетичного перекладу, перекладацькими тактиками і стратегіями роботи 3 поетичними текстами та актуальними проблемами поетичного перекладу [1, с. 7]. Основні завдання, відповідно, торкаються як загально-теоретичної, так і практичної площини [2; 3]. Таким чином, ознайомлення $з$ історією перекладу поетичних текстів, аналіз основних тенденцій та відстеження змін у підході до перекладу, формування уявлення про основні теоретичні моделі поетичного перекладу сприятимуть розвитку вмінь та навичок аналізу зразків перекладу та розробки цілісної стратегії застосування перекладацьких прийомів у перекладі поетичних текстів.

Необхідною передумовою успішного досягнення мети $є$ наявність високого рівня підготовки студентів, що передбачає опанування як загальних, так і вузьких дисциплін перекладознавства. Отже, у навчальній програмі даним курс має слідувати за курсами лексикології, історії мови, зіставної стилістики. Щобільше, такі курси загальноосвітніх дисциплін, як культурологія, естетика, історія i теорія літератури та філософія сприятимуть всебічному і глибокому аналізу поетичних творів задля подальшого їх розгляду у перекладацькій площині.

Практичний аспект зазначеного курсу охоплює декілька напрямків роботи $з$ поетичними текстами. По-перше, це розвиток уміння аналізу перекладацьких тактик та стратегій, застосованих до поетичних текстів [1, с. 8]. На даному етапі важливими виявляються фонові знання для інтерпретації історичного та культурного аспекту перекладу. Також, на перший план виходить і особистість перекладача як транслятора власних цінностей та поглядів у контексті певної епохи. Таким чином, у роботі з поетичними перекладами крізь критичне мислення дослідника розкриваються найдрібніші деталі, що складаються у калейдоскоп рими, ритму та образності поетичного тексту [3, с. 134-136].

Наступний етап - вияв творчого начала майбутніх переклада_ чів. Опанувавши теоретичні засади підвалин поетичного перекладу та опрацювавши приклади роботи перекладачів, студенти, використовуючи набуті знання, створюють свій власний алгоритм перекладу поетичних текстів. Досягненню цієї мети сприятимуть розроблені тактики та стратегії поетичного перекладу відповідно до характеру тексту. 
Таким чином, зазначена побудова курсу - від теоретичної частини, крізь практику аналізу тестів, до перших спроб власного перекладу сприятиме ефективному опануванню матеріалу з виходом у власний творчий переклад. Зважаючи на прогрес сьогодення, а саме розвиток штучного інтелекту i його застосування у різних видах перекладу, розробка та введення курсу з поетичного перекладу до навчальної програми $є$ необхідною умовою для підтримання високого рівня навчання майбутніх перекладачів.

\title{
Література:
}

1. Абдрахманова О.Р. Роль переводческой ошибки в обучении переводу. Вестник Челябинского государственного университета. Серия: Филология. Искусствоведение. Вып. 88. № 6 (335). 2014. С. 6-9.

2. Коптілов В.В. Актуальні питання українського художнього перекладу. Київ : Дніпро, 1972. 132 с.

3. Ляшко Я. М. Поетичний переклад як особливий вид творчої діяльності (на матеріалі перекладів Р. М. Рільке). Наукові записки НДУ ім. М. Гоголя. Серія: Філологічні науки. Книга 4. 2014. С. 133-136.

DOI https://doi.org/10.30525/978-9934-26-073-5-2-66

\section{TO THE QUESTIONS OF FORMATION OF COLLECTIVE THINKING THROUGH THE CONNECTIVISM EDUCATIONAL PRINCIPLE IN DISTANT LEARNING IN MARITIME ENGLISH ON UNIFIED COMMUNICATION PLATFORM}

\author{
Ivasiuk N. A. \\ Candidate of Pedagogical Sciences, \\ Professor at the English Language Department \\ National University "Odessa Maritime Academy» \\ Odesa, Ukraine
}

Following our idea from the previous publications [1, 2, 3, 4] of creating Unified Communication Platform (UCP) for seafarers as international distant Maritime English (ME) learning instrument we made the attempt to create the sample learning environment for navigators, marine engineers and ship managers, which can be, of course, potentially expanded and improved in exponential ways. Previously we studied modern researches of scientists $[5,6,7,8]$ concerning distant learning technologies, analyses of differential 